Diunggah : November 2021

Diterima : Januari 2022

Dipublikasi : Januari 2022

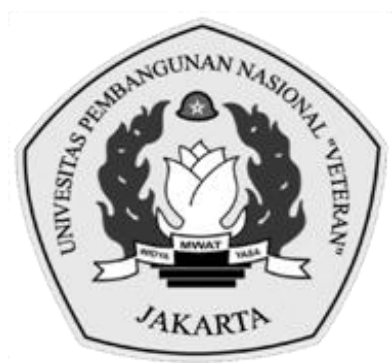

\title{
DETERMINAN KEMANDIRIAN KEUANGAN PADA PEMDA TINGKAT II DI PROVINSI JAWA TENGAH
}

\author{
Annafi Indra Tama ${ }^{1 *}$, Isti Pujihastuti ${ }^{2}$ \\ 1annafi.tama@gmail.com, 2istipujihastuti333@gmail.com \\ 1,2 Universitas Islam 45 Bekasi, Indonesia \\ *Penulis Korespondensi
}

\begin{abstract}
Abstrak
Penitian ini bertujuan untuk melihat pengaruh Dana Alokasi Khusus (DAK), Belanja Modal, Tingkat Partisipasi Angkatan Kerja, dan Pendapatan Asli Daerah (PAD) terhadap Kemandirian Keuangan Daerah. Tahun pengamatan yang dilakukan dimulai dari tahun 2017 sampai tahun 2019, sedangkan pobjek penelitian dalam penelitian ini dilakukan pada Pemda Tingkat II di Provinsi Jawa Tengah. Dalam penelitian ini metode analisis yang digunakan adalah analisis regresi linier berganda. Populasi dan sampel dalam penelitian ini meliputi kabupaten/kota di Jawa Tengah, dan periode penelitian berlangsung dari tahun 2017 hingga 2019. Dalam penelitian ini digunakan strategi purposive sampling dengan memilih sampel sebanyak 102 titik data. DAK, Belanja Modal, Tingkat Partisipasi Angkatan Kerja, dan PAD ditemukan berdampak pada kemandirian keuangan daerah. DAK dan Belanja Modal berpengaruh negatif cukup besar terhadap kemandirian keuangan daerah, sedangkan PAD berpengaruh positif signifikan, sedangkan tingkat partisipasi angkatan kerja tidak berpengaruh.
\end{abstract}

Kata Kunci: DAK; Belanja Modal; PAD; Kemandirian Keuangan.

\begin{abstract}
This research aims to see the effect of the Special Allocation Fund, Capital Expenditure, Labor Force Participation Rate, and Regional Original Income on Regional Financial Independence. The year of observation was carried out starting from 2017 to 2019, while the research object in this study was conducted at the Level II Regional Government in Central Java Province. In this research, the analytical method used is multiple linear regression analysis. The population and sample in this study covered districts/cities in Central Java, and the research period lasted from 2017 to 2019. In this study, a purposive sampling strategy was used by selecting a sample of 102 data points. Special Allocation Fund, Capital Expenditure, Labor Force Participation Rate, and Regional Original Income were found to have an impact on regional financial independence. Special Allocation Fund and Capital Expenditures have a significant negative effect on regional financial independence, while Regional Original Income has a significant positive effect, while the level of labor force participation has no effect.
\end{abstract}

Keywords: Special Allocation Fund; Capital Expenditures; Regional Original Income; Financial Autonomy

\section{PENDAHULUAN}

Pemerintah Pusat mendelegasikan kewenangan kepada Pemda (Pemda) sebagaimana diatur dalam UU 32 Tahun 2004 agar Pemda mandiri dari Pemerintah Pusat dan otonomi daerah berfungsi secara efektif. Namun demikian, 
masih terdapat hambatan dalam pelaksanaan otonomi daerah, terutama adanya ketimpangan fiskal antar daerah. Untuk mengisi kekurangan tersebut, Pemerintah Pusat memberikan bantuan (transfer) kepada Pemda, serta Dana Alokasi Umum (DAU) dan Dana Alokasi Khusus (DAK), yang semuanya ditetapkan dan dikelola oleh Pemerintah Pusat.

Ada berbagai alasan untuk ketergantungan Pemda pada Pemerintah Pusat; Pemekaran penduduk salah satunya, namun tidak dibarengi dengan peningkatan penerimaan negara. Seperti diketahui, DAU setiap daerah dialokasikan berdasarkan ketimpangan anggaran dan alokasi dasar. Kesenjangan fiskal didefinisikan sebagai kebutuhan fiskal dikurangi kapasitas fiskal. Alokasi Dasar, di sisi lain, ditentukan oleh pendapatan Pegawai Negeri Sipil di daerah tersebut.

Keharusan Provinsi dan Kabupaten/Kota memperjuangkan pendapatan asli daerah yang lebih tinggi. Perbandingan Pendapatan Asli Daerah (PAD) dengan pendapatan dari Pemerintah Pusat menunjukkan kemandirian keuangan daerah. Jika rasio PAD tinggi, ketergantungan Pemda terhadap dana dari Pemerintah Pusat akan berkurang. Apabila Pemda mampu membiayai pengeluarannya sendiri dengan PAD yang diterimanya, maka dianggap efektif dalam melaksanakan otonomi daerah dan desentralisasi fiskal.

Berdasarkan Peraturan Pemerintah No. 104 Tahun 2004, DAU, DAK, dan bentuk lain dari transfer Pemerintah Pusat hanya dimaksudkan untuk membantu pelaksanaan pembangunan pemerintah dan daerah. Hal ini menunjukkan bahwa Pemda belum sepenuhnya independen dari Pemerintah Pusat dalam mengendalikan rumah tangga daerah, terbukti dengan ketergantungan yang lebih besar pada DAU dan DAK guna mendukung pengeluaran daripada pendapatan daerah.

Penitian ini bertujuan untuk melihat pengaruh Dana Alokasi Khusus (DAK), Belanja Modal, Tingkat Partisipasi Angkatan Kerja, dan Pendapatan Asli Daerah (PAD) terhadap Kemandirian Keuangan Daerah. Beberapa penelitian telah dilakukan mengenai tingkat kemandirian keuangan daerah. Temuan penelitian sebelumnya pada variabel Dana Alokasi Umum (DAU). Menurut Tahar et al. (2011), DAU berdampak negatif terhadap kemandirian keuangan daerah, namun menurut temuan penelitian lain yang dilakukan Sari (2015), DAU berpengaruh positif dan signifikan. tentang kemandirian keuangan daerah. Temuan beberapa penelitian tentang variabel Dana Alokasi Khusus (DAK) yang dilakukan oleh Kustianingsih, et al. (2018) menunjukkan bahwa DAK berpengaruh negatif signifikan terhadap tingkat kemandirian finansial, namun temuan ini bertentangan dengan temuan Nursei (2019), yang menemukan bahwa DAK tidak berpengaruh terhadap tingkat kemandirian keuangan Pemda. Arnawati (2015) merangkum temuan beberapa penelitian tentang variabel Belanja Modal, menyimpulkan bahwa Belanja Modal berpengaruh positif terhadap kemandirian keuangan daerah, sedangkan Darwis (2015) menyatakan Belanja Modal berpengaruh negatif terhadap kemandirian keuangan daerah. Marizka (2013) menemukan Pendapatan Asli Daerah (PAD) berpengaruh positif terhadap kemandirian keuangan daerah, namun temuan penelitian ini bertentangan dengan penelitian Nurhasanah (2017) yang mengklaim bahwa PAD tidak berpengaruh terhadap kemandirian keuangan daerah.

Penelitian ini dilakukan di Wilayah Tingkat II Provinsi Jawa Tengah. Provinsi 
Jawa Tengah pada tahun 2020 dianugrahi penghargaan dari Otoritas Jasa Keuangan Republik Indonesia (OJK RI), antara lain provinsi dengan inovasi pengembangan program keuangan inklusi terbaik, Penghargaan Sederhana, dan penghargaan khusus Ganjar sebagai figur penggerak terbaik program inklusi keuangan. Penghargaan tersebut menunjukkan bahwa keuangan Provinsi Jawa Tengah dapat secara efektif menangani sistem keuangannya. Oleh karena itu, peneliti berkeinginan untuk melakukan penelitian tambahan mengenai keadaan keuangan kabupaten dan kota di Provinsi Jawa Tengah.

Hasil penelitian menunjukkan bahwa DAK dan Belanja Modal berpengaruh negatif cukup besar terhadap kemandirian keuangan daerah, sedangkan PAD berpengaruh positif signifikan, sedangkan tingkat partisipasi angkatan kerja tidak berpengaruh. Hasil penelitian ini diharapkan dapat memberikan masukan kepada Pemerintah Pusat maupun Pemerintah Daerah untuk menyoroti hal-hal apa saja yang dapat berpengaruh terhadap penurunan kemandirian keuangan daerah. Selanjutnya, penelitian ini disusun sebagai berikut: Bagian 2 mengulas penelitian tentang determinan kemandirian daerah dan teori yang mendasari penelitian ini. Bagian 3 dan 4 membahas metode dan hasil pengujian dan analisis penelitian ini, dan Bagian 5 menyajikan kesimpulan dan implikasi penelitian.

\section{TINJAUAN PUSTAKA}

\section{Landasan Teori \\ Teori Stakeholder}

Menurut Friedman, istilah pemegang saham pertama kali digunakan oleh Stanford Research Institute (RSI) pada tahun 1963. Stakeholder, menurut Friedman, adalah "setiap kelompok atau individu yang dapat mempengaruhi atau dipengaruhi oleh pencapaian tujuan organisasi." Mereka adalah "kelompok atau individu yang dapat mempengaruhi atau dipengaruhi oleh proses pencapaian tujuan organisasi." Menurut teori pemangku kepentingan, ada hubungan antara pemegang kekuasaan dan pemangku kepentingan untuk mencapai tujuan organisasi. Berkenaan dengan itu, karena baik penyelenggaraan maupun pemenuhan Anggaran Pendapatan dan Belanja Daerah (APBD) akan berdampak langsung pada kesejahteraan rakyat, maka pemerintah harus menyelenggarakan pemerintahannya secara bijaksana guna mewujudkan good governance.

Teori Agensi

Teori keagenan, menurut Jensen dan Smith (1984), adalah sebuah konsep yang menggambarkan hubungan kontraktual antara prinsipal dan agen. Agen berwenang untuk melakukan segala tindakan atas nama prinsip dalam kapasitasnya sebagai pengambil keputusan untuk mencapai tujuan yang sama. Hubungan antara Pemerintah Pusat dan Pemda dalam penelitian ini mencontohkan hubungan antara teori keagenan dan praktik keagenan. Hubungan antara Pemerintah Pusat dan Pemda analog dengan hubungan antara prinsipal dan agen dalam bisnis. Prinsipal adalah Pemerintah Pusat, dan agen adalah pemerintah lokal. Pemerintah Pusat memercayai Pemda untuk mengelola daerahnya dengan menggunakan uang transfer, dengan tujuan memberikan pemerataan pelayanan 
kepada masyarakat dan mensejahterakan masyarakat. Masalah keagenan akan terjadi jika dana yang dikelola oleh Pemda tidak mencapai output yang maksimal dan merugikan Pemerintah Pusat.

Pendapatan Badan Usaha Milik Daerah merupakan salah satu jenis keuangan daerah yang dipisahkan (BUMD). Yang dimaksud dengan pengelolaan keuangan daerah adalah keseluruhan kegiatan perencanaan, pelaksanaan, penatausahaan, pelaporan, pertanggungjawaban, dan pengawasan keuangan daerah dalam Pasal 1 ayat (7). Kegiatan pengelolaan keuangan daerah tercermin dari pengelolaan APBD.

\section{Kemandirian Keuangan}

Pengukuran pendapatan asli daerah (PAD) relatif terhadap pendapatan daerah dari sumber lain, seperti dukungan Pemerintah Pusat atau pinjaman, digunakan untuk menentukan kemandirian keuangan daerah (Halim, 2007:232). Rasio Kemandirian keuangan daerah dapat menggambarkan tingkat partisipasi masyarakat dalam pembangunan daerah. Dimana semakin besar partisipasi masyarakat dalam membayar pajak dan retribusi daerah dimana bagian dari PAD maka akan semakin meningkatkan rasio kemandiriannya daerah tersebut.

\section{Dana Alokasi Khusus}

Dana Alokasi Khusus (DAK) berasal dari pendapatan APBN. DAK dialokasikan oleh kepala daerah untuk membantu pendanaan kegiatan khusus yang ada atau dilaksanakan di daerah. Dana Alokasi Khusus berfungsi sebagai wujud fisik tugas pemerintahan di bidang tertentu, khususnya dalam upaya memenuhi kebutuhan sarana dan prasarana pelayanan umum yang esensial, seperti rumah sakit, pendidikan, jalan, pasar, irigasi, dan air bersih.

\section{Belanja Modal}

Sejumlah dana yang digunakan untuk belanja kebutuhan invenstasi daerah didefinisikan sebagai Belanja Modal. Berdasarkan Permendagri nomor 13 dan 53 Tahun 2006, belanja modal dikeluarkan untuk pembelian/pengadaan atau pembangunan aset tetap berwujud dan memiliki masa manfaat lebih dari 12 bulan. Belanja aset tersebut dapat digunakan dalam kegiatan pemerintahan, seperti seperti tanah, peralatan dan mesin, gedung dan gedung, jalan, irigasi dan jaringan, dan aset tetap lainnya. Belanja modal dalam APBD dikategorikan sebagai bagian dari belanja langsung.

\section{Tingkat Partisipasi Angkatan Kerja}

Angkatan kerja menurut Sukirno (2004:18), adalah banyaknya pekerja dalam perekonomian pada suatu waktu yang meliputi orang-orang yang bekerja dan orang-orang yang menganggur dan sedang mencari pekerjaan. Beberapa yang bukan termasuk angkatan kerja meliputi mereka yang masih sekolah, yang mengurus rumah tangga, dan lain-lain.

Besar kecilnya angkatan kerja ditentukan oleh partisipasi angkatan kerja, atau berapa persen dari yang akan bergabung dengan angkatan kerja, serta pengertian angkatan kerja yang diartikan sebagai porsi angkatan kerja yang melakukan kegiatan produktif, seperti memproduksi barang. dan layanan. Rasio antara jumlah pekerja dan penduduk usia kerja digunakan untuk menghitung 
TPAK (Badan Pusat Statistik, 2018)

Rumus 1. Perhitungan Tingkat Pastisipasi Angkatan Kerja

$$
T P A K=\frac{\text { jumlah angkatan kerja }}{\text { Jumlah penduduk usia kerja }} \times 100 \%
$$

\section{Pendapatan Asli Daerah}

Pasal 1 Undang-Undang Nomor 33 Tahun 2004 mendefinisikan pendapatan asli daerah (PAD) sebagai pendapatan yang diterima oleh daerah dan dipungut sesuai dengan peraturan perundang-undangan daerah dan peraturan perundangundangan. PAD merupakan pendapatan yang menjadi salah satu sumber pembiayaan pembangunan daerah. Namun, PAD belum tentu mampu memberikan kontribusi terhadap pertumbuhan daerah dan kemandirian daerah. Oleh karena itu, perlu adanya penelitian lanjutan, khususnya PAD dan pengaruhnya terhadap kemandirian daerah

\section{Pengembangan Hipotesis}

\section{Dampak Dana Alokasi Khusus terhadap Kemandirian Keuangan di Daerah}

Pemerintah Pusat dan provinsi (prinsipal) mendelegasikan wewenang kepada Pemda (agen) untuk melaksanakan wewenang yang dilimpahkan, sedangkan Pemda bertanggung jawab kepada Pemerintah Pusat untuk mengelola uang alokasi khusus. Pemda dipercaya oleh Pemerintah Pusat untuk mentransfer dana untuk mengelola daerahnya sendiri guna memaksimalkan pelayanan publik. Menurut Yani (2002:166), Dana Alokasi Khusus (DAK) berguna dalam mendanai kegiatan-kegiatan khusus. Kegiatan tersebut dapat menjadi isu daerah dan prioritas nasional. Dengan kata lain, daerah tersebut masih memiliki pendapatan asli daerah yang rendah dan harus meningkatkan dan mengembangkan daerahnya sendiri. Dalam melakukan tindakan seperti peningkatan kualitas sekolah dengan membangun/menyediakan sarana dan prasarana, digunakan dana alokasi khusus. Sekalipun Dana Alokasi Khusus Pemerintah Pusat cukup signifikan, daerah tersebut belum mandiri secara fiskal karena masih bergantung pada dana dari Pemerintah Pusat sebagai sumber pendapatan utamanya. Artinya semakin banyak DAK yang dialokasikan oleh Pemerintah Pusat, semakin besar kemandirian keuangan daerah; sebaliknya semakin kecil Dana Alokasi Khusus yang diterima daerah maka semakin besar kemandirian keuangan daerah.

Dana Alokasi Khusus berpengaruh negatif signifikan terhadap Tingkat Kemandirian Daerah Kabupaten Kota di Sulawesi Tengah, menurut (Kustianingsih, dkk., 2018), dan (Marizka, 2013) menyatakan bahwa dana alokasi khusus berpengaruh negatif dan berpengaruh signifikan terhadap tingkat kemandirian keuangan daerah di Provinsi Sumatera Barat, dan (Anggia, 2018) menyatakan bahwa dana alokasi khusus berpengaruh negatif terhadap tingkat kemandirian keuangan daerah di Sumbar.

Hipotesis penelitian berikut ditawarkan berdasarkan uraian sebelumnya adalah:

H1: Dana Alokasi Umum berdampak negatif terhadap kemandirian keuangan di daerah. 


\section{Dampak Belanja Modal terhadap Kemandirian Keuangan Daerah}

Yang dimaksud dengan belanja modal adalah semua pengeluaran negara yang dilakukan dalam rangka pembentukan modal berupa tanah, peralatan dan mesin, gedung dan gedung, jaringan, dan bentuk fisik lainnya, menurut UndangUndang Nomor 18 Tahun 2016. Belanja modal memiliki ciri khas yang menyiratkan faktor yang berbeda untuk dipertimbangkan ketika mengalokasikan dana. Pemda harus memaksimalkan potensi pendapatannya untuk mendorong kemandirian daerah, dan salah satu caranya adalah dengan membelanjakan sebagian besar anggarannya untuk pembangunan di sektor-sektor produktif daerah (Harianto dan Adi, 2007).

Belanja modal biasanya digunakan untuk memperoleh aset tetap yang dapat digunakan untuk pembangunan daerah. Tingkat kemandirian daerah dalam membiayai kegiatannya, terutama dari segi keuangan, diperkirakan akan meningkat seiring dengan kemajuan pembangunan. Semakin besar jumlah belanja modal yang dimiliki, maka semakin banyak pula infrastruktur dan fasilitas yang dibangun.

Teori pemangku kepentingan yang menjelaskan bagaimana kelompok dan individu dapat mempengaruhi atau dipengaruhi oleh tujuan organisasi digunakan untuk mendukung variabel Pengeluaran Modal dan variabel Tingkat Kemandirian Keuangan Daerah dalam penelitian ini. Dapat dijelaskan bahwa Pemda sebagai roda pemerintahan pemegang kekuasaan harus mengutamakan kepentingan warga sebagai pemangku kepentingan. Stakeholder theory menjelaskan bagaimana pemerintah mengatur kebijakan anggaran yang pro (setuju) kepada rakyat dengan melihat realisasi belanja modal, karena belanja modal sangat erat kaitannya dengan pembangunan sarana dan prasarana, serta sarana dan prasarana untuk kebaikan. pelayanan publik, maka akan mendorong masyarakat untuk berkontribusi kepada daerah, yang nantinya dapat meningkatkan pendapatan asli daerah, yang menjadi faktor utama dalam menentukan pro (setuju) pemerintah terhadap rakyat.

Belanja modal berpengaruh positif namun tidak signifikan terhadap tingkat kemandirian keuangan daerah menurut (Sari, 2015), dan belanja modal berpengaruh positif terhadap tingkat kemandirian keuangan daerah menurut (Arnawati, 2015) dan hasil penelitian (Simatupang, 2016), dan jika belanja meningkat maka tingkat kemandirian keuangan daerah akan meningkat.

Selanjutnya berdasarkan penelitian sebelumnya dapat dikembangkan hipotesis sebagai berikut:

H2: Belanja modal berdampak positif terhadap tingkat kemandirian keuangan suatu daerah.

\section{Dampak Tingkat Partisipasi Angkatan Kerja Terhadap Kemandirian Finansial di Daerah}

Tingkat partisipasi angkatan kerja yang besar mencontohkan kesejahteraan masyarakat; tingkat partisipasi angkatan kerja berpengaruh signifikan terhadap tingkat pendapatan daerah. Ketika tingkat partisipasi angkatan kerja naik di suatu daerah, berdampak pada pendapatan asli daerah melalui perolehan pajak penghasilan $(\mathrm{PPh})$ yang juga naik. Sebagai contoh, di daerah pedesaan di Indonesia, seperti Kabupaten Klungkung dan Bangli yang banyak penduduknya menganggur, Pemda menerima pajak penghasilan yang semakin berkurang, 
sehingga kesejahteraan daerah yang dimiliki semakin berkurang, sedangkan di Kabupaten Badung, pendapatan daerah semakin berkurang. sebaliknya terjadi, dengan tingkat partisipasi TNI meningkat. Pekerjaan berpengaruh pada jumlah pajak penghasilan yang dipungut oleh daerah, yang semakin meningkat, mengakibatkan peningkatan pendapatan daerah (Blane, 2003).

Teori pemangku kepentingan yang menjelaskan bagaimana kelompok atau individu dapat mempengaruhi atau dipengaruhi oleh tujuan organisasi digunakan untuk mendukung variabel tingkat partisipasi angkatan kerja pada variabel Tingkat Kemandirian Keuangan Daerah dalam penelitian ini. Dapat dijelaskan bahwa Pemda sebagai roda pemerintahan pemegang kekuasaan harus mengutamakan kepentingan warga sebagai pemangku kepentingan. Stakeholder theory menjelaskan bagaimana pemerintah mengatur kebijakan anggaran yang pro (setuju) kepada rakyat, dengan melihat penyerapan tenaga kerja di daerah menunjukkan bahwa pembangunan ekonomi di daerah semakin membaik, sehingga tingkat partisipasi angkatan kerja yang tinggi akan mendorong masyarakat. memberikan kontribusi kepada daerah yang nantinya akan meningkatkan Pendapatan Asli Daerah (PAD) yang menjadi faktor utama dalam mendorong tingkat kemandirian keuangan daerah.

\section{H3 : Tingkat partisipasi angkatan kerja berdampak positif terhadap tingkat kemandirian keuangan daerah}

\section{Dampak Pendapatan Asli Daerah terhadap Kemandirian Keuangan di Daerah}

Pendapatan atau pendapatan daerah diperoleh melalui pemungutan berdasarkan peraturan daerah sesuai dengan peraturan perundang-undangan, menurut Undang-Undang Nomor 33 Tahun 2004 tentang Perimbangan Keuangan antara Pemerintah Pusat dan Pemda. Menurut Sidik dalam Wirawan (2007), tingkat kemandirian keuangan daerah akan meningkat seiring dengan ekspansi di PAD. Kontribusi (porsi) PAD terhadap belanja daerah mencerminkan tingkat otonomi daerah tersebut.

Teori pemangku (Stakeholder Theory) kepentingan mendukung variabel bebas pendapatan asli daerah serta variabel terikat kemandirian keuangan daerah. Menurut teori pemangku kepentingan, Pemda sebagai pemegang kekuasaan dalam roda pemerintahan harus mengutamakan kepentingan warga sebagai pemangku kepentingan. Dikarenakan pembangunan sarana dan prasarana serta sarana dan prasarana yang berkaitan dengan pelayanan dan kesejahteraan umum, maka tingkat pendapatan asli daerah yang diterima oleh Pemda merupakan sumber pendanaan utama bagi Pemda untuk memenuhi kebutuhannya dalam rangka peningkatan sarana dan prasarana. berkaitan dengan pelayanan publik. Tingkat kemandirian keuangan daerah akan digalakkan oleh masyarakat.

Berdasarkan hasil penelitian (Lestari et al., 2016), (Kustianingsih et al., 2018), dan (Amalia, 2019), Pendapatan Asli Daerah berpengaruh baik dan signifikan terhadap kemandirian keuangan daerah Pemerintah Provinsi Sulawesi Tenggara. . Jika pendapatan asli daerah meningkat, maka kemandirian keuangan daerah juga meningkat, karena dapat dibuktikan bahwa partisipasi masyarakat dalam membayar kewajibannya membantu mendanai kebutuhan Pemda untuk memperluas pembangunan dan fasilitas bagi masyarakat. Di sisi lain, jika pendapatan daerah buruk, kemandirian keuangan daerah juga rendah.

Peneliti berkeyakinan bahwa Pendapatan Asli Daerah (PAD) berdampak baik 
terhadap kemandirian keuangan daerah, berdasarkan alasan tersebut di atas. Karena pendapatan asli daerah yang relatif tinggi akan meningkatkan pendapatan daerah dan meminimalkan ketergantungan kepada Pemerintah Pusat. Wilayah ini dapat digambarkan sebagai wilayah yang independen karena ketergantungannya pada Pemerintah Pusat telah berkurang.

\section{H4 : Pendapatan Asli Daerah berdampak positif terhadap tingkat kemandirian keuangan daerah.}

\section{METODOLOGI PENELITIAN}

Penelitian ini termasuk dalam kategori penelitian kuantitatif, yang mencoba menjelaskan hubungan dan pengaruh dua atau lebih gejala atau faktor, yang kemudian diolah untuk sampai pada hasil.

\section{Populasi dan Sampel}

Populasi dalam penelitian ini adalah seluruh Pemda Kabupaten/Kota Jawa Tengah yang berjumlah 35 Pemda pada tahun 2017-2019. Pendekatan nonprobability sampling dengan teknik purposive sampling digunakan untuk menentukan jumlah sampel dalam penelitian ini. Kriteria tertentu telah diidentifikasi sebagai hal yang penting untuk tujuan penelitian. Dalam penelitian ini, kriteria data yang digunakan sebagai sampel adalah:

1. Laporan Keuangan Pemda (LKPD) yang lengkap

2. Laporan Keuangan Pemda Kabupaten/Kota di Jawa Tengah tahun 2017-2019 yang telah diaudit oleh Badan Pemeriksa Keuangan Republik Indonesia (BPKRI).

\section{Definisi Operasional dan Pengukuran Variabel Tingkat Kemandirian Keuangan Daerah}

Kemandirian keuangan Pemda mengacu pada kemampuan mereka untuk mendanai sendiri kegiatan, pelayanan, dan pengembangan masyarakat (Darise, 2007). Total pendapatan daerah dibagi dengan dukungan Pemerintah Pusat/provinsi dan pinjaman untuk menentukan kemandirian keuangan daerah. Rasio kemandirian daerah merupakan ukuran kemandirian keuangan suatu daerah (Ernawati, 2017).

Rumus 2. Perhitungan Tingkat Kemandirian Keuangan Daerah

$$
T K K D=\frac{\text { Realisasi PAD }}{\begin{array}{c}
\text { Bantuan Pemerintah Pusat/Provinsi dan } \\
\text { Pinjaman }
\end{array}} \times 100 \%
$$

\section{Dana Alokasi Khusus}

Jumlah uang transfer yang diterima daerah selain dana lokasi umum digunakan untuk menghitung Dana Alokasi Khusus.

\section{Belanja Modal}

Pengeluaran Modal adalah istilah yang digunakan untuk menggambarkan 
jumlah uang yang dibelanjakan untuk belanja. Menurut Darise (2007: 148) belanja modal adalah pembelian/pengadaan aset tetap dan aset lainnya dengan masa manfaat lebih dari satu periode akuntansi yang digunakan dalam kegiatan pemerintah, seperti tanah, peralatan dan mesin, gedung dan gedung, jalan. , irigasi, jaringan, dan belanja modal lainnya. Belanja Modal = Belanja Tanah + Belanja Peralatan dan Mesin + Belanja Gedung dan Bangunan + Belanja Jalan, Irigrasi, dan Jaringan + Belanja Aset Tetap Lainnya.

\section{Pendapatan Asli Daerah}

Pendapatan Asli Daerah (PAD) adalah pendapatan yang dipungut oleh daerah sesuai dengan peraturan perundang-undangan berdasarkan peraturan daerah (Halim, 2008). Rumus 3 berikut digunakan untuk menghitung pendapatan asli daerah (PAD) (Bastian, 2002):

Rumus 3. Perhitungan Pendapatan Asli Daerah

PAD = Pajak daerah + Retribusi daerah + Hasil pengelolaan kekayaan daerah yang dipisahkan + Lain-lain PAD yang sah

\section{Teknik Analisis Data}

\section{Analisis Regresi Berganda}

Tujuan dari analisis regresi berganda yang digunakan dalam penelitian ini adalah untuk menunjukkan hubungan antara variabel terikat dan variabel bebas, serta besarnya hubungan tersebut. Pada variabel terikat Tingkat Kemandirian Keuangan Daerah, variabel bebasnya adalah Dana Alokasi Khusus, Belanja Modal, Tingkat Partisipasi Angkatan Kerja, dan Pendapatan Asli Daerah.

Uji statistik deskriptif, uji asumsi klasik, dan uji regresi berganda digunakan untuk menguji data dalam penelitian ini. Berikut ini adalah persamaan regresi berganda yang akan digunakan:

Rumus 4. Model Regresi Penelitian

$$
Y=\alpha-\beta_{1} X_{1}-\beta_{2} X_{2}+\beta_{3} X_{3}+\beta_{4} X_{4}+\varepsilon
$$

Keterangan :

$\begin{array}{ll}\mathrm{Y} & : \text { Tingkat Kemandirian Keuangan Daerah } \\ \alpha & : \text { Konstanta } \\ \beta_{1}, \beta_{2}, \beta_{3}, \beta_{4}, \beta_{5}, \beta_{6} & : \text { Koefisien variabel independen dengan variabel dependen } \\ X_{1} & : \text { Dana Alokasi Khusus } \\ X_{2} & : \text { Belanja Modal } \\ X_{3} & : \text { Tingkat Partisipasi Angkatan Kerja } \\ X_{4} & : \text { Pendapatan Asli Daerah } \\ \varepsilon & : \text { error term model }\end{array}$

\section{HASIL DAN PEMBAHASAN}

Setelah dilakukan pencarian sampel ditetapkan Kabupaten/Kota Jawa Tengah yang akan dijadikan sampel, dan populasi yang ada akan dipilih dengan teknik purposive sampling berdasarkan kriteria yang telah ditetapkan. Hasil 
yang dikumpulkan dan yang memenuhi kriteria berasal dari 34 kabupaten/kota di Jawa Tengah, tempat penelitian berlangsung selama tiga tahun, dari 2017 hingga 2019, menghasilkan 102 sampel data.

Uji Koefisien Determinasi

Tabel 1. Hasil pengujian

\begin{tabular}{lllll}
\hline & Adjusted & F & T & Sig. \\
& R & Hitung & Hitung & \\
& Square & & & \\
\hline DAK & .517 & 27.089 & -9.226 & .000 \\
Bel.Modal & & & -2.930 & .004 \\
TPAK & & & -.225 & .823 \\
PAD & & & 18.347 & .000 \\
\hline
\end{tabular}

Sumber: Hasil Output SPSS 17, 2021

Nilai Adjusted R Square sebesar 0,517 atau 51,7 persen, menurut tabel 1. Hal ini menunjukkan bahwa Tingkat Kemandirian Keuangan Daerah dikuasai sebesar 51,7 persen oleh Dana Alokasi Khusus, Belanja Modal, Tingkat Partisipasi Angkatan Kerja, dan Pendapatan Asli Daerah, sedangkan 48,3 persen dipengaruhi oleh faktor lain yang tidak dibahas dalam penelitian ini.

Uji F menghasilkan nilai Fhitung sebesar 27,089 (signifikansi $\mathrm{f}=0,000$ ) sebagai hasil dari hasil tersebut. Akibatnya, sig 0,05. Hal ini menandakan bahwa variabel bebas $(\mathrm{X})$ dan variabel terikat (Y) saling mempengaruhi (Y). Untuk menentukan apakah suatu penelitian berpengaruh secara parsial atau tidak, $\mathrm{T}$ tabel harus ditentukan terlebih dahulu. Nilai ttabel sebesar 1,65055 dapat diperoleh dengan memanfaatkan tabel distribusi t dengan tingkat signifikansi 0,05.

\section{Dana Alokasi Khusus terhadap Tingkat Kemandirian Keuangan Daerah}

Hasil evaluasi variabel Dana Alokasi Khusus pada tabel 1 menunjukkan pengaruh negatif yang cukup besar terhadap Tingkat Kemandirian Keuangan Daerah, hal ini menunjukkan bahwa hipotesis H1 diterima. Tingkat Kemandirian Keuangan Daerah akan meningkat jika Dana Alokasi Khusus yang termasuk dalam uang transfer dari Pemerintah Pusat berkurang. Karena daerah lebih banyak menggunakan uang daerah dalam melaksanakan pelayanan pemerintah, alokasi Dana Alokasi Khusus pemerintah yang lebih kecil diproyeksikan akan mengurangi ketergantungan Pemda terhadap dana yang disediakan oleh Pemerintah Pusat, sehingga memungkinkan kemandirian keuangan daerah yang lebih besar.

Temuan penelitian ini sependapat dengan (Tahar, Afrizal, dan Zakhiya, 2011), yang menyatakan bahwa jika Dana Alokasi Khusus suatu daerah kecil, kemandirian daerah akan lebih besar karena Pendapatan Asli Daerah akan memainkan peran yang lebih besar secara total. pendapatan APBD. Apabila daerah belum menggunakan dan memanfaatkan Dana Alokasi Khusus yang dialokasikan oleh Pemerintah Pusat secara efektif dan efisien, berarti penggunaan dana tersebut belum memenuhi tujuan alokasi dana transfer. kurangnya kemandirian keuangan di daerah Akibatnya, Dana Alokasi Khusus tampaknya memiliki dampak merugikan yang besar terhadap kemandirian keuangan daerah.

Peneltiian yang dilakukan oleh Ekasari (2015) menyatakan bahwa dana 
alokasi khusus berdampak negative terhadap kemandirian keuangan daerah. Hal tersebut sejalan dengan hasil penelitian yang dilakukan bahwa dengan semakin kecilnya dana alokasi khusus yang diterima maka kemandirian keuangan daerah semakin besar. Daerah harus mampu mengoptimalkan keuangannya untuk dapat menjalankan perekonomian secara lancar.

\section{Belanja Modal Terhadap Tingkat Kemandirian Keuangan Daerah}

H3 ditolak berdasarkan hasil penelitian variabel belanja modal (tabel 1) yang mengungkapkan bahwa belanja modal berpengaruh negatif cukup besar terhadap tingkat kemandirian keuangan daerah. Hal ini menunjukkan bahwa ketika belanja modal naik, kemandirian keuangan daerah turun, dan sebaliknya, ketika belanja modal turun, kemandirian keuangan daerah meningkat. Temuan analisis ini sejalan dengan penelitian (Darwis, 2015) dan (Nindita, 2018) yang menunjukkan belanja modal memiliki dampak merugikan yang cukup besar terhadap kemandirian keuangan daerah.

Belanja modal Pemda tidak serta merta menghasilkan kemandirian keuangan daerah yang lebih besar. Belanja untuk pembangunan sarana dan prasarana di desa-desa kecamatan, serta sarana dan prasarana untuk pelayanan umum seperti perbaikan jalan dan pembangunan irigasi. Hal ini tidak akan menaikkan jumlah Pendapatan Asli Daerah yang dihasilkan oleh daerah, tetapi akan meningkatkan jumlah pengeluaran yang harus ditanggung daerah dengan menggunakan Pendapatan Asli Daerah dan bahkan uang transfer yang diberikan oleh Pemerintah Pusat. Contoh lainnya adalah pembelian tanah atau bangunan sebagai aset daerah yang tidak dikelola dan dimanfaatkan dengan baik, sehingga aset tersebut menjadi aset terbengkalai dan investasi dalam belanja modal tidak meningkatkan pendapatan asli daerah, yang akan membuat daerah mandiri.

\section{Tingkat Partisipasi Angkatan Kerja terhadap Tingkat Kemandirian Keuangan Daerah}

Hasil penelitian variabel tingkat partisipasi angkatan kerja pada tabel 1 menunjukkan bahwa tingkat partisipasi angkatan kerja tidak berpengaruh secara substansial terhadap kemandirian keuangan daerah, maka H3 ditolak. Hal ini menunjukkan bahwa tingkat partisipasi angkatan kerja di suatu daerah tidak berpengaruh terhadap tingkat kemandirian keuangan daerah.

Temuan penelitian ini sejalan dengan penelitian (Ulandari, 2019) yang menyatakan bahwa tingkat partisipasi angkatan kerja tidak berpengaruh signifikan terhadap kemandirian keuangan daerah. Hal ini menunjukkan bahwa di kabupaten/kota Jawa Tengah mayoritas angkatan kerja tidak berdampak langsung terhadap kemandirian keuangan daerah.

Salah satu temuan studi tersebut terlihat pada data sampel Kabupaten Purbalinga dari tahun 2017 hingga 2019, yang menunjukkan tingkat partisipasi angkatan kerja sebesar 71 persen hingga 70 persen dan terus turun menjadi 685, tanpa adanya peningkatan kemandirian keuangan daerah. Hal ini menunjukkan bahwa tingkat partisipasi angkatan kerja yang digunakan untuk menilai kesehatan ekonomi suatu daerah tidak memiliki pengaruh langsung terhadap kemandirian keuangan daerah. Total Tingkat partisipasi angkatan kerja yang tinggi hanya akan 
berpengaruh jangka panjang terhadap kondisi keuangan daerah.

Pertumbuhan angkatan kerja sebagai akibat dari hal tersebut di atas tampak menunjukkan bahwa peningkatan tenaga kerja justru menurunkan kesejahteraan. Sumber Daya Manusia (SDM) merupakan salah satu upaya untuk memperoleh informasi penting untuk mengukur efektivitas dan efisiensi pelaksanaan program sehingga dapat digunakan sebagai dasar untuk menentukan arah pengembangan sumber daya manusia dan ketenagakerjaan ke depan.

\section{Pendapatan Asli Daerah terhadap Tingkat Kemandirian Keuangan Daerah}

Tabel 1 menunjukkan hasil penelitian terhadap variabel Pendapatan Asli Daerah. Jika Pendapatan Asli Daerah berpengaruh positif kuat terhadap Tingkat Kemandirian Keuangan Daerah, maka H4 diterima. Hal ini menunjukkan bahwa ketika pendapatan asli daerah meningkat, maka tingkat kemandirian keuangan daerah juga meningkat. Temuan penelitian ini menguatkan penelitian-penelitian sebelumnya yang kesemuanya menunjukkan bahwa pendapatan asli daerah memiliki dampak yang cukup menguntungkan bagi kemandirian keuangan daerah (Marizka (2013); Amalia (2019); dan Yulianto (2018)).

Ketika PAD suatu daerah melebihi jumlah bantuan yang diterima dari Pemerintah Pusat dan pinjaman dari pihak ketiga atau orang lain, dasrah itu mandiri secara finansial dan dapat meminimalkan ketergantungannya pada Pemerintah Pusat. Daerah dapat dikatakan mandiri karena ketergantungan Pemda terhadap Pemerintah Pusat berkurang. Dengan demikian, dapat disimpulkan bahwa pendapatan asli daerah memiliki dampak positif yang besar terhadap kemandirian keuangan daerah.

\section{SIMPULAN}

Penelitian ini dilakukan untuk mengetahui pengaruh dana laokasi khusus, belanja modal, tingkat partisipasi angkatan kerja dan pendapatan asli daerah terhadap kemandirian keuangan daerah. Penelitian ini dilakukan pada hasil Laporan Keuangan Pemerintah Daerah (LKPD) tingkat II Provinsi Jawa Tengah. Analisis regresi berganda digunakan sebagai metoda analisis untuk mengukur pengaruh varibael bebas terhadap variabel terikat.

Hasil penelitian menunjukkan bahwa Dana Alokasi Khusus (DAK) berpengaruh negatif signifikan terhadap kemandirian keuangan daerah. DAK yang lebih rendah dari Pemerintah Pusat diharapkan dapat mengurangi ketergantungan Pemda terhadap dana transfer yang disediakan oleh Pemerintah Pusat, sehingga kemandirian keuangan daerah dapat terwujud. Belanja modal memiliki dampak merugikan yang besar terhadap kemandirian keuangan di daerah. Belanja modal Pemda tidak serta merta menghasilkan kemandirian keuangan daerah yang lebih besar. Pengeluaran Pemda untuk pelayanan publik seperti pemeliharaan jalan atau pembangunan irigasi di desa-desa di kabupaten tidak akan meningkatkan Pendapatan Asli Daerah yang dihasilkan oleh daerah, berimplikasi bahwa belanja modal tidak akan menghasilkan Kemandirian Keuangan Daerah.

Partisipasi angkatan kerja tidak berpengaruh terhadap kemandirian keuangan daerah karena jika keterlibatan tenaga kerja perempuan meningkatkan 
rasio di masyarakat, hal itu disebabkan kurangnya kesejahteraan rumah tangga di daerah tersebut, sehingga memaksa perempuan untuk turun tangan dan mencari pekerjaan. Hal ini tampaknya menunjukkan bahwa kenaikan biaya tenaga kerja menurunkan kesejahteraan. Pendapatan Asli Daerah (PAD) menjadi variabel yang mempengaruhi secara signifikan terhadap kemandirian keuangan daerah. PAD yang semakin besar berdampak kepada ketergantungan keuangan daerah tersebut terhadap dana bantuan dari Pemerintah Pusat/Provinsi.

Penelitian ini dapat memberikan kontribusi pada Pemda untuk dapat menggali lebih dalam lagi terkait dengan potensi sumber daya yang dimiliki. Dengan optimalisasi yang dilakukan tersebut Pemda dapat meningkatkan pendapatan asli daerah masing-masing. Selain itu, hasil penelitian ini dapat menjadi perhatian bagi Pemerintah Pusat terhadap daerah yang masing tertinggal sangat dibutuhkan untuk dapat meningkatkan kemampuan keuangan daerah tersebut dan membantu mereka agar tidak tergantung secara terus menerus terhadap Pemerintah Pusat/Provinsi.

Penelitian ini memiliki beberapa keterbatasan. Penelitian ini hanya mengambil sampel di kabupaten/kota di Jawa Tengah sehingga hasil penelitian kurang dapat digeneralisasi terhadap Pemda di daerah lain di Indonesia. Penelitian selanjutnya agar dapat mengambil sampel yang lebih luas cakupannya agar lebih dapat digeneralisasi. Selain itu, penelitian ini juga tidak mempertimbangkan faktor kematangan daerah yang mungkin saja mempengaruhi tingkat kemandirian daerah. Dengan demikian, penelitian selanjutnya dapat meneliti variabel lain seperti tingkat kematangan perangkat daerah.

\section{DAFTAR PUSTAKA}

Amalia, Afifah Fauziah N. (2019). Analisis Pengaruh Pendapatan Asli Daerah, Dana Alokasi Umum, Dan Belanja modal Terhadap Tingkat Kemandirian Keuangan Daerah Pada Pemerintah Daerah Kabupaten/Kota Di Provinsi Jawa Tengah Tahun 2012-2017. Penelitian. Semarang , Universitas Diponogoro, 2015.

Andriani, R. Neneng R., dan Wahid Nisa N. (2018). Pengaruh Pendapatan Asli Daerah dan Dana Perimbangan terhadap Tingkat Kemandirian Keuangan Daerah (Studi Kasus pada Pemerintah Kota Tasikmalaya Tahun 200-2015. Jurnal Akuntansi. Tasikmalaya, Universitas Siliwangi, 2018.

Arief, Imam., dan Hidayatullah, N. (2018). Pengaruh Belanja modal, Pendapatan Asli Daerah, Dana Alokasi Umum, dan Dana Alokasi Khusus terhadap Tingkat Kemandirian Keuangan Daerah. Penelitian. Jakarta, UPN Veteran Jakarta.

Ariani, Kurnia Rina. (2010). Pengaruh Belanja modal dan Dana Alokasi Umum terhadap Tingkat Kemandirian Keuangan Daerah dan Tax Effort (Studi Kasus pada Pemerintah Kabupaten/Kota Wilayah Eks Karesidenan Surakarta). Penelitian. Surakarta: Universitas Sebelas Maret.

Arnawati, P. Gustita., dan Ariani, Kurnia Rina. (2010). Pengaruh Belanja modal Dan Dana Alokasi Umum Terhadap Kemandirian Daerah. Seminar Nasional. Surakarta: Universitas Muhammadiyah Surakarta. 
Ayu, Anggia. (2018). Pengaruh Dana Alokasi Umum, Dana Alokasi Khusus, Dana Bagi Hasil, dan Belanja modal terhadap Tigkat Kemandirian Keuangan Daerah Pemerintah Kabupaten/Kota Provinsi Lampung Tahun 2013-2016. Penelitian. Bandar Lampung: Universitas Lampung.

Blane D. Lewis. 2003. Tax And Charge Creation By Regional Governments Under Fiscal Decentralisation: Estimates And Explanations. Bulletin Of Indonesian Economic Studies. 39(2): 177-192.

Darwis, Erstelita. T. R. (2009). Pengaruh Belanja modal dan Belanja Pegawai Terhadap Tingkat Kemandirian Keuangan Daerah pada Kabupaten/Kota Provinsi Sumatera Barat. Jurnal Akuntansi. Padang: Universitas Negeri Padang.

Ernawati dan Ikhsan Budi R. (2017). Pengaruh Kinerja Pendapatan Asli Daerah dan Belanja modal terhadap Kemandirian Keuangan Daerah Kabupaten/Kota Provinsi Jawa Timur. Jurnal Ilmu dan Riset Akuntansi. STIESIA Surabaya Vol. 6 (2) ISSN: 2460-0585.

Ghozali, Imam. (2013). Aplikasi Analisis Multivariate dengan Program IBM SPSS 19. Semarang: Badan Penerbit Universitas Diponegoro.

Ghozali, Imam. (2018). Aplikasi Analisis Multivariate Dengan Program IBM SPSS 25. Semarang: Badan Penerbit Universitas Diponegoro.

Halim, Agung. (2007). Akuntansi Keuangan Daerah. Edisi 3. Jakarta: Salemba Empat.

Halim, Abdul. (2008). Akuntansi Keuangan Daerah. Edisi Revisi 3. Jakarta: Salemba Empat.

Ismi, Rizky dan Suryo. (2009). Pengaruh PAD dan Belanja Pembangunan terhadap Rasio Kemandirian dan Pertumbuhan Ekonomi. Konferensi Penelitian Keuangan Sektor Publik II.

Kustianingsih, N., dkk. (2018). Pengaruh Pendapatan Asli Daerah (PAD), Dana Alokasi Umum (DAU), Dana Alokasi Khusus (DAK) terhadap Tingkat Kemandirian Daerah Pada Pemerintah Daerah Kabupaten Kota di Provinsi Sulawesi Tengah. Palu: Universitas Tadulako. ISSN Vol. 6.

Lestari, Anita., dkk. (2016). Pengaruh Dana Alokasi Umum (Dau) Dan Pendapatan Asli Daerah (PAD) terhadap Belanja modal dan Kemandirian Keuangan Daerah Provinsi Sulawesi Tenggara. Jurnal Progres Ekonomi Pembangunan. Universitas Halu Oleo. Vol. 1, No. 2. 2016.

Mahmudi. (2016.) Analisis Laporan Keuangan Pemerintah Daerah. Edisi ketiga. Yogyakarta: Unit Penerbit Percetakan Sekolah Tinggi Ilmu Manajemen YKPN.

Mahsun, Moh. (2006). Pengukuran Kinerja Sektor Publik. Yogyakarta: BPFE.

Marizka, Reza. (2013). Pengaruh Pendapatan Asli Daerah, Dana Bagi Hasil, Dana Alokasi Umum dan Dana Alokasi Khusus terhadap Tingkat Kemandirian Keuangan Daerah pada Kabupaten dan Kota Di Sumatera Barat Tahun 2006-2011). Artikel Ilmiah. Padang: Universitas Negeri Padang.

Muliana. (2009). Pengaruh Rasio Efektivitas PAD, DAU, dan DAK terhadap Kemandirian Keuangan Daerah. Penelitian. Medan: Fakultas Ekonomi Sumatra Utara.

Ulandari, Ida Ayu, dan Purbadharmaja. (2019). Analisis Faktor-Faktor Yang Mempengaruhi Kemandirian Keuangan dan Kesejahteraan Daerah 
Kabupaten/Kota Provinsi Bali. Jurnal EP Unud. Bali: Universitas Udayana.

Nindita, Nareswari L., dan Rahayu, Sri. (2018). Pengaruh Pendapatan Asli Daerah (PAD), Dana Alokasi Umum (DAU), serta Belanja modal terhadap Tingkat Kemandirian Keuangan Daerah Kabupaten/Kota Provinsi Jawa Barat. Journal Accounting and Finance. Bandung: Universitas Telkom. Vol. 2 No. 1

Novalistia, R. L. (2016). Pengaruh Pajak Daerah, Retribusi Daerah, Lain-Lain Pendapatan Asli Daerah yang Sah dan Bagi Hasil Pajak Terhadap Tingkat Kemandirian Keuangan Daerah Pada Pemerintah Kabupaten atau Kota di Provinsi Jawa Tengah (Studi Empiris Pada Kabupaten/Kota Provinsi Jawa Tengah. Journal Of Accounting. Semarang: Universitas Pandanaran Semarang.

Nugraha, Yoga Nurdiana. (2019). Desentralisasi dan Ketergantungan Fiskal Daerah. Dalam detikNews, 30 Januari 2019. Jakarta.

Nurhasanah dan Maria. (2017). Faktor-Faktor yang Mempengaruhi Tingkat Kemandirian Keuangan Daerah pada Pemerintahan Kabupaten dan Kota di Provinsi Bengkulu. Jurnal Riset Terapan Akuntansi. Vol. 1 No.1.

Peraturan Menteri Dalam Negeri Nomor 59 Tahun 2007 pasal 26 tentang Pedoman Pengelolaan Keuangan Daerah.

Peraturan Menteri Keuangan Nomor 127/PMK.02/2016 tentang Klasifikasi Anggaran.

Perawati. (2019). Pengaruh Pendapatan Asli Daerah (PAD), Dana Alokasi Umum (DAU), dan Dana Alokasi Khusus (DAK) terhadap Tingkat Kemandirian Keuangan Pemerintah Daerah Kabupaten/Kota di Sumatera Selatan. Penelitian. Palembang: Universitas Muhammadiyah Palembang.

Putro, Prima Utama W. (2013). Pengaruh PDRB, Ukuruan dan Pendapatan Asli Daerah dengan Pendapatan Asli Daerah sebagai Variabel Intervening. Penelitian Sarjana. Semarang: Universitas Negeri Semarang.

Sari, Putri Ika. (2015). Pengaruh Dana Alokasi Umum, Dana Alokasi Khusus dan Belanja modal terhadap Tingkat Kemandirian Keuangan Daerah (Studi Kasus Pada Kabupaten/Kota Di Diy Periode 2007-2014). Artikel. Yogyakarta: Universitas PGRI Yogyakarta.

Simatupang, Ferian Fernando. (2016). Pengaruh Dana Perimbangan, Belanja modal dan Belanja Pegawai terhadap Tingkat Kemandirian Keuangan Daerah pada Pemerintah Kabupaten/Kota di Provinsi Sumatera Utara (2010-2013). Penelitian. Medan: Universitas Sumatera Utara.

Sugiyono. 2017. Metode Penelitian Kuantitatif, Kualitatif, dan R\&D. Alfabeta.

Tahar, Afrizal dan Zakhiya, M. (2011). Pengaruh Pendapatan Asli Daerah Dan Dana Alokasi Umum Terhadap Kemandirian Daerah Dan Pertumbuhan Ekonomi Daerah. Jurnal Akutansi Dan Investasi. Yogyakarta: Universitas Muhammadiyah Yogyakarta.

Tjahjono, Achmad., dan Oktavianti, Rika. (2017). Pengaruh Rasio Efektivitas Pendapatan Asli Daerah, Dana Alokasi Umum Dan Dana Alokasi Khusus Terhadap Tingkat Kemandirian Keuangan Daerah Di Provinsi DIY. Kajian Bisnis. Yogyakarta: STIE Widya Wiwaha Yogyakarta.

Undang-Undang Republik Indonesia Nomor 33 Tahun 2004 tentang Perimbangan Keuangan Antara Pemerintah Pusat dan Pemerintahan Daerah.

Yani, Ahmad. (2002). Hubungan Keuangan Antara Pemerintah Pusat dan Daerah Di 
Indonesia. Jakarta: Raja Grafindo Persada.

Yulianto, Andri. (2018). Analisis Pengaruh Pendapatan Asli Daerah, Dana Alokasi Umum, Dana Alokasi Khusus Dan Belanja modal Terhadap Tingkat Kemandirian Keuangan Daerah. Penelitian. Surakarta: Universitas Muhammadiyah Surakarta. 